

\title{
THE FUTURE OF PUBLIC POLICY
}

\author{
Hugh Compston \\ Department of Politics \\ Cardiff School of European Studies \\ Cardiff University \\ Compston@Cardiff.ac.uk
}

Post-print: version accepted for publication in World Futures, 64(1) 2008: 43-59

\begin{abstract}
This article reports the results of research that uses policy network theory and advocacy coalition theory to deduce the implications for the future of public policy in EU Member States of king trends: all those technological, economic, environmental and social trends that can be empirically verified, affect the lives of large numbers of people and are expected by relevant experts to continue for at least the next 20 years. The resulting policy implications can be summarized as more assertive security policies, more business-friendly economic policies, more liberal social policies and increased public spending.
\end{abstract}




\section{Introduction}

Where is public policy in European countries heading? Will we get tax cuts or better public services? How will pensioners fare? Will public policy become more and more attuned to the needs of business at the expense of other groups? Will public policy become more Europeanized and globalized?

Although ultimately we cannot tell for sure because there are too many unknowables, it is possible to obtain a theoretically-informed synoptic picture of the matrix of long-term pressures exerted on public policy by major long-term technological, economic, environmental and social trends. This article sets out the results of a major research project designed to do just this for the Member States of the European Union (Compston 2006). The 12 long-term policy implications that emerge can be summarised as more assertive security policies, more business-friendly economic policies, more liberal social policies and increased public spending.

The following sections describe in turn my theoretical approach, my methodology, and results of applying this methodology.

\section{Theory}

My approach is based on two of the most prominent contemporary theories of policy-making: policy network theory and Sabatier's Advocacy Coalition Framework (ACF).

The main defining characteristic of policy network theory is its focus on the patterns of formal and informal contacts and relationships between government and non-government decision-makers (policy actors) as influences on policy-making (Parsons 1995: 185). Perhaps the most prominent version, and the one on which I shall concentrate, is that put forward by Rod Rhodes. This views policy-making as consisting largely of a process of exchanges of resources using specific political strategies within understood 'rules of the game' (Rhodes 1985: 4-5).

As the factors that determine policy outcomes in what is effectively a model of bargaining, namely bargaining strategies, power resources and coalition possibilities, also determine the membership of the policy network (Dowding 1995), it follows that if these characteristics of policy actors don't change, policy shifts will remain fairly small, since network membership and the balance of power among network members will remain much the same. This means that for major policy change to occur there must first be pre-existing changes in the views, bargaining strategies, power resources or coalition possibilities of network members. Such changes are caused mainly if not exclusively by developments and events external to policy networks themselves. An example will make this clear. Business groups would be expected to gain bargaining power as the internationalisation of production renders more plausible corporate threats to shift investment elsewhere if their policy demands are not met, which in turn implies greater pressure on governments to shift public policy in a pro-business direction, but the driver for this change, the internationalisation of production, is a factor external to the network.

The Advocacy Coalition Framework (ACF) was developed by Paul Sabatier as a way of bringing into focus the role of ideas within a holistic theory of policy-making. It portrays public policy as the outcome of interactions within policy subsystems (networks) between contending advocacy coalitions each of which is bound together by common beliefs about what policy should be, such as free traders and protectionists in relation to trade, or hawks and doves in relation to defence (Sabatier and Jenkins-Smith 1999). Sabatier sees policy change as resulting from two main sources. The first of these is policy-oriented learning within and between 
advocacy coalitions. Secondary aspects of coalition belief systems - beliefs about the appropriate instruments with which to implement their policy core - are most affected by this, with policy cores themselves being less affected and deep cores - the fundamental beliefs and axioms on which the policy core is based - rarely affected at all. Major policy changes, by contrast, are seen as the result of external perturbations - changes in government, turnover of personnel in key positions and changes in relevant socio-economic conditions - that alter the composition and/or resources of the contending advocacy coalitions.

In other words, both policy network theory and advocacy coalition theory see major policy change as being caused by the impact of external developments and events on policy networks. It follows that if we can ascertain what these events are going to be, we should be able to get some idea of the direction of future policy change through examining their impact on policy actors, networks and advocacy coalitions.

But there is a problem. It is generally impossible to predict what these events are going to be, especially in the long term. It is difficult to predict the results of the next election, for example, let alone a sequence of future elections. We are constantly subjected to a blizzard of unforeseen events. How then can policy network theory and advocacy coalition theory be used to obtain an indication of the directions in which public policy is likely to move?

The key insight is the observation that there is at least one class of events that can be predicted, namely the events that constitute major long-term technological, economic, environmental and social trends. More specifically, it is possible to predict the events that constitute trends that are well-established, significant for people's lives and expected by experts to continue for the next 20 years or so. These I call king trends to stress their significance and distinguish them from other trends. We can predict with confidence, for example, that, barring major disruptions such as an energy crisis, GDP and incomes will continue to rise. We can predict that international trade and capital movements will expand. We can predict that people aged 65 or over will become a greater proportion of the population as time goes on. We can predict that global warming will continue. Many such trends can be identified.

Given this, in principle we can then go on to predict how these trends are likely to affect policy actors and networks and, through this, influence the future direction of public policy. To show how this can be done I take Sabatier's ACF as my point of departure, but the logic applies equally to network theory.

Recall that, according to Sabatier, major policy changes are the result of external perturbations that alter the composition and/or resources of contending advocacy coalitions.

For the composition of an advocacy coalition to change there must be (a) a change in the membership of the policy network as a whole, for example due to powerful multinational firms entering or leaving the country, or (b) a change in the views of one or more policy actors that leads them to switch coalitions, such as a political party (or its leadership) becoming convinced that global warming is real and consequently joining environmentalist coalitions in areas such as transport policy.

For the resources of an advocacy coalition to change, logically there must either be a change in its composition, as discussed above, or a change in the resources of one or more of its members. Internationalization of production, for example, would be expected to add to the 
resources of pro-business coalitions by enabling their business members more plausibly to threaten to redirect investment to other countries if their policy demands are not met.

In short, we can establish how king trends affect the composition and/or resources of contending advocacy coalitions if we can establish how these trends affect policy network composition and/or the views and/or resources of individual policy actors. This means identifying how king trends (a) cause policy actors to enter and leave policy networks, (b) alter the views of one or more policy actors, or (c) alter the resources of one or more policy actors.

The final step is to identify the implications of this for the direction of public policy. Once we can identify changes in policy network composition and/or the views and/or resources of policy actors, we can use the provisions of the ACF (or network theory) to deduce the direction in which these changes would be expected to push public policy, other things being equal. More specifically, altering network composition and/or the views and/or resources of individual policy actors would be expected to lead to different policy outcomes than would have occurred without these changes. If the bargaining resources of business vis a vis national governments increase, for example, we can predict that pressure on public policy to become more pro-business will grow as time goes on, other things being equal. Similar predictions can be made in relation to the implications for public policy of changes in policy network composition and in the policy views of policy actors.

This approach can be made clearer by conceptualizing the direction of policy change as the resultant of a parallelogram of pressures brought to bear by the views, resources and political strategies of relevant policy actors. If these views, resources and strategies remain the same, the main lines of public policy remain the same. When they alter, the balance of pressures alters and public policy changes accordingly. If we can identify how king trends alter the views, resources and strategies of policy actors - or at least their resources - we should be able to deduce changes to one or more lines of pressure operating on public policy and therefore specify not the net resultant policy change, because the parallelogram of pressures is being inflected by short-term trends and fluctuations as well as by individual events and personalities, but the directions in which the underlying king trends are pushing public policy before being inflected by shorterterm pressures.

\section{Methodology}

Putting my approach into practice for European countries involves four main steps: (1) identification of king trends, (2) identification of policy actors and their resources, (3) evaluation of the effects of these trends on policy actors, and (4) evaluation of the direction of consequent pressures on public policy.

\section{Identification of King Trends}

To be predictable, a trend must be believed to be likely to continue well into the future. To be of interest, it must be significant in some way. To be included in the analysis as a king trend, therefore, a trend must meet three conditions:

1. Its existence as a major current trend in European democracies such as Britain, France and Germany must be convincingly verified;

2. There must be strong evidence that it directly affects the lives of a large number of people in a significant way; 
3. It must be expected by relevant experts to be likely to continue operating for at least the next 20 years, for example because it has been operating for a very long time already, because the factors sustaining it are themselves expected to continue to operate, or because there are no obvious countervailing factors on the horizon.

Table 1 lists the 19 trends that meet all three criteria and can therefore be classified as king trends. For more details see Compston 2006.

Table 1. Identifiable king trends

\begin{tabular}{|c|c|}
\hline Type & Trend \\
\hline $\begin{array}{l}\text { Development and } \\
\text { spread of } \\
\text { technological } \\
\text { innovation }\end{array}$ & $\begin{array}{l}\text { 1. Information and communications technology } \\
\text { 2. Biotechnology } \\
\text { 3. Healthcare technology } \\
\text { 4. Military technology }\end{array}$ \\
\hline Economic trends & $\begin{array}{l}\text { 5. Growth and diversification of production and consumption } \\
\text { 6. Greater energy use } \\
\text { 7. Increasing mobility } \\
\text { 8. The shift to services } \\
\text { 9. The growth of women's employment } \\
\text { 10. The expansion of trade } \\
\text { 11. The internationalisation of production } \\
\text { 12. The internationalisation of finance } \\
\text { 13. The expansion of mass media }\end{array}$ \\
\hline Environmental trends & 14. Climate change \\
\hline Social trends & $\begin{array}{l}\text { 15. Population ageing } \\
\text { 16. Rising levels of education } \\
\text { 17. Smaller households } \\
\text { 18. Secularisation } \\
\text { 19. Sexual liberalisation }\end{array}$ \\
\hline
\end{tabular}

\section{Identification of Policy Actors and Resources}

The next step is to identify the relevant policy actors, by which is meant those individuals and groups who take an interest in the policy issues raised by the trend under consideration or who are affected by the trend or its consequences. Table 2 sets out the indicative policy network model used as a point of departure for identifying the specific policy networks that are affected by each king trend. It focuses mainly on policy actors, resources and strategies because policy views tend to be specific to the policy area being analyzed and are therefore not suited to inclusion in a generic model. The model adapts Sabatier's model of policy subsystems (networks) to the European context and includes eight different types of policy actor, each of which possesses characteristic types of policy resources that can be used in political exchange over public policy. The model also includes the electorate as a sort of quasi-policy actor on the grounds that political executives often alter public policy in direct response to signals from the 
electorate via public opinion polls, focus groups, direct action such as demonstrations, and election results. For ease of exposition it is focused mainly on the level of the nation state, but this should not obscure the fact that other levels of governance are also important: in many areas the EU level is dominant, while in other areas subnational levels of government take the lead.

Table 2. Generic policy network

\begin{tabular}{|c|c|}
\hline Policy actor & Power resources \\
\hline $\begin{array}{l}\text { Political executive: head of } \\
\text { government (and possibly head of } \\
\text { state) plus relevant minister(s), and } \\
\text { their parties }\end{array}$ & $\begin{array}{l}\text { Legal authority, command of civil service expertise, } \\
\text { support within their party, support within cabinet, } \\
\text { support within the legislature, electoral support }\end{array}$ \\
\hline $\begin{array}{l}\text { Other politicians: opposition parties, } \\
\text { faction leaders/rebels, leaders at } \\
\text { European level, sub-national level, } \\
\text { foreign leaders }\end{array}$ & $\begin{array}{l}\text { Relevant expertise, legal authority, capacity to deliver } \\
\text { legislative support, perceived capacity to deliver } \\
\text { popular support, capacity to take legal action, } \\
\text { capacity to apply diplomatic, economic or military } \\
\text { pressure }\end{array}$ \\
\hline $\begin{array}{l}\text { Civil servants: lead ministry/agency, } \\
\text { finance ministry, other ministries and } \\
\text { agencies, European, subnational, } \\
\text { international }\end{array}$ & $\begin{array}{l}\text { Access to the political executive, relevant expertise, } \\
\text { the role of drafting policy proposals, the capacity to } \\
\text { facilitate or obstruct policy implementation, } \\
\text { independent legal authority }\end{array}$ \\
\hline Judges and regulators & Legal authority \\
\hline Business, especially corporations & $\begin{array}{l}\text { Access to the political executive and civil servants, } \\
\text { relevant expertise, money, capacity to facilitate or } \\
\text { obstruct policy implementation, capacity to take legal } \\
\text { action, capacity to take direct action }\end{array}$ \\
\hline $\begin{array}{l}\text { Non-government organizations: } \\
\text { employers and unions, other interest } \\
\text { groups, social movements such as } \\
\text { greens; national, sectoral, European, } \\
\text { sub-national }\end{array}$ & $\begin{array}{l}\text { Access to the political executive and civil servants, } \\
\text { relevant expertise, money, capacity to facilitate or } \\
\text { obstruct policy implementation, perceived capacity to } \\
\text { deliver popular support, capacity to take legal action, } \\
\text { capacity to take direct action }\end{array}$ \\
\hline Media (television, press) & Perceived capacity to deliver popular support \\
\hline Non-government experts & Relevant expertise \\
\hline Electorate & $\begin{array}{l}\text { Votes, capacity to facilitate or obstruct policy } \\
\text { implementation, capacity to take direct action }\end{array}$ \\
\hline
\end{tabular}




\section{Evaluation of the Effects of Each Trend on Policy Actors}

Once a king trend is identified, the next step is to investigate the extent to which it leads either to policy actors entering or leaving policy networks or to changes in their views or resources. This involves using the official and academic expert literature relating to the king trend under consideration to help extrapolate causal connections forward from the king trend in order to identify impacts on network composition or on the views or resources of policy actors. Since governments often alter public policy in direct response to signals from the electorate, such as opinion polls, due to their desire for re-election, the study also examines the impact of king trends on factors that influence electoral turnout and voter choice.

\section{Evaluation of the Direction of Consequent Pressures on Public Policy}

Once it is clear how each trend affects the composition of policy networks and the views and resources of policy actors, the final step is to unpack the implications of these effects for the direction of public policy.

According to policy network theory the appearance of a new policy actor, or a significant strengthening of their resources, should lead to pressure for public policy to move in the direction desired by that policy actor, other things being equal. Conversely, the disappearance of a policy actor from a network, or a significant weakening in their resources, should lessen or remove pressure for public policy to move in their direction. Increasing the bargaining power of corporations, for example, would be expected to lead to increased pressure on public policy in move in a pro-business direction, while a decline in the membership of mainstream churches would be expected to reduce pressure for public policy to conform to traditional Christian values.

For Sabatier, however, advocacy coalitions are the focus rather than individual policy actors, and major policy change is seen as the result of changes in the composition and resources of contending advocacy coalitions. This means that before the ACF can be applied, it is necessary to draw out the implications for advocacy coalitions of the impact of king trends on policy actors. For example, the implications of any increase in the policy-relevant resources of corporations would need to be translated into changes in the resources of contending advocacy coalitions in areas such as economic policy and environmental policy. Once this is done, conclusions can be drawn concerning the pressure exerted by these changes on the direction of public policy. If the resources of an advocacy coalition increase as a result of the impact of longterm trends, we would expect that this would increase pressure for the content of public policy to move closer to that advocacy coalition's policy core, other things being equal. If an advocacy coalition's resources diminish, for example because a member leaves, we would expect a lessening of pressure for public policy to move in its direction.

A similar logic can be applied to changes in the factors that influence electoral turnout and voter choice insofar as these changes are caused by king trends, as these can be translated into greater or lesser electoral pressure for particular types of policies. A growing preponderance of relatively old people in the electorate, for example, would be expected to lead to greater electoral pressure for good quality services for the elderly, other things being equal. 


\section{Results}

Using the above procedure yielded over a hundred findings concerning the policy implications of each king trend considered individually on an 'other things being equal' basis (Compston 2006). These can be condensed into 12 points that, taken together, constitute an integrated baseline projection of the net directions in which king trends considered as a whole are pushing public policy in EU countries before these pressures are inflected by events, personalities and other short-term and unpredictable factors. This is as close as we can get to a synoptic view of the long-term future direction of public policy.

At the most general level, the net policy implications of the 19 king trends can be summarized as more assertive security policies, more business-friendly economic policies, more liberal social policies and increased public spending. To understand what this means, however, it is necessary to look beyond these four general headings to the 12 specific policy implications that they cover.

\section{More Assertive Security Policies}

\section{1 . More Assertive Foreign and Security Policies.}

EU governments have both the incentive and the opportunity to implement more assertive foreign and security policies in coming years except in relation to major trading partners. The perceived threats posed by the proliferation of weapons of mass destruction, cyber-attacks on vital computer systems and dependence on energy imports are growing, while ever-increasing levels of production create a constant need to open up new markets in other countries. At the same time the development of precision warfare techniques capable of quick victories with few or no casualties and minimum destructiveness reduces the electoral cost of military action. The result is likely to be more aggressive and interventionist foreign and security policies except in relation to major trading partners, as the expansion of international trade and production networks with these countries increases the domestic economic costs of their being disrupted by military action.

\section{$\underline{2 .}$ More Intrusive and Internationalized Law Enforcement.}

EU governments also have both the incentive and opportunity to implement more vigorous measures against crime. The king trends operating today imply rising crime in a number of respects. There is the perception that developments in information and communications technology (ICT) are leading to increasing levels of computer crime. The expansion of trade and the internationalization of production and finance are thought to be increasing the incidence of international crime such as fraud and money laundering. Increasing independence of mind due to rising levels of education implies rising levels of white-collar crime as increasing numbers of people decide for themselves whether to obey the law. There is evidence that children brought up in one-parent families are more likely to commit crime than children from two-parent families, which implies that the increasing incidence of one-parent families means rising crime, other things being equal, although this tendency is offset somewhat by the declining proportion in the population of the category of people most likely to commit crime, namely young men, due to population ageing. And secularization weakens inhibitions against crime and anti-social behavior by weakening the hold of Christian morality. At the same time the potential effectiveness of law enforcement is being increased by improvements in surveillance technology. The likely results are moves to tighten regulation of ICT, implement tighter border controls, permit law 
enforcement agencies to increase their use of surveillance, introduce harsher penalties for criminal acts, and expand international cooperation in law enforcement.

\section{More Business-Friendly Policies}

The king trends operating today strengthen the economic and electoral incentives for governments to shift public policy in a more business-friendly direction in a number of ways, although not all of these are motivated solely by a concern to help business and their effects are not necessarily beneficial only to business. We begin by looking at the policy implications relating to specific types of firms and sectors.

3. More Favorable Policies towards Expanding Firms and Sectors.

As time goes on some types of business become more significant for growth and employment, thus increasing the economic and electoral incentives for governments to do what they can to assist them and take advantage of what they do, while others become less economically significant and therefore of lesser political importance except to the extent that their difficulties cause economic or social disruption. The main types of expanding firms and sectors are hi-tech firms, the services sector in general, transnational companies (TNCs), exporters, international financial institutions and media companies. Increasing international competition means that import-competing firms are the ones most at risk of sudden meltdown.

The increasing significance of technological developments in areas such as ICT, biotechnology and healthcare strengthen the incentives for governments to implement more vigorous measures to assist firms in these areas, for instance by expanding financial incentives for technology-rich incoming foreign investment, adapting process and product regulation in ways that facilitate the development and use of new technologies (for example by loosening restrictions on the use of genetic tests by insurers and employees as these tests become more reliable), and expanding direct financial incentives such as tax breaks for R\&D. The growing economic significance of new technology also provides incentives for governments to encourage other businesses to use these technologies, expand education and training so that employees are appropriately skilled in their use, and intensify efforts to protect businesses from cybercrime.

The increasing economic importance of services relative to manufacturing strengthen the incentives for governments to make public policy more services-friendly in areas such as regulation, education and training, access to government services, technical and generic assistance to small and medium-sized enterprises, tax policy and financial support. Similarly, the increasing economic value of the media industry increases the incentives for governments to make public policy more favorable towards media interests in areas such as regulation and industry assistance.

The increasing economic importance of export industries, combined with growing competition for foreign markets and increasing competition from imports for domestic importcompeting industries, strengthen the incentives for governments to assist export and importcompeting producers to compete by means such as improving infrastructure, expanding education and training, providing additional assistance with $R \& D$, increasing direct financial aid, implementing more vigorous measures to open up new markets in foreign countries, cutting employers' social contributions and corporation tax, taking steps to secure wage restraint, reforming employment regulation to increase labor flexibility, and reducing the costs to business 
of environmental regulation. An alternative strategy is to strengthen international labor and environmental standards in order to restrict low-cost competition in these areas.

The increasing economic importance of TNCs and inward foreign investment, plus the increasing ability of resident companies to move production elsewhere, strengthen the incentives for governments to implement policies designed to benefit TNCs such as further liberalization of investment restrictions and greater incentives for inward foreign investment as well as the policies already mentioned in the areas of technology, tax, education, infrastructure, labor costs, employment regulation, environmental regulation and trade policy. At the same time the pressure exerted on public policy by TNC threats to withhold investment, or move it elsewhere, can be countered by using international agreements to limit locational competition by means such as harmonizing tax regimes, investment regulation and labor and environmental standards, although progress in this area is likely to be limited by the opposition of current 'winners' in these fields to signing international agreements that remove their comparative advantages.

The increasing economic importance of TNCs also implies a change in the economic policy instruments used by governments, since the ability of TNCs to shift profits elsewhere undermines tax revenue and means that demand management policies have less impact, while their currency dealings undermine exchange rate policy, their capacity to shift production elsewhere undermines industrial policy, and their ability to borrow elsewhere or transfer domestic borrowings elsewhere means that monetary policy has less impact on credit. In these circumstances measures to stimulate business activity, such as the ones listed above, become increasingly important as policy instruments.

The increasing economic importance of international financial markets, combined with the financial importance for governments of minimizing interest rates on government debt, increase the incentives for governments to implement more business-friendly policies as defined by financial markets. Apart from those listed above this means strict policies to control inflation, which are already in place in the EU, and further international financial liberalization. However the extent to which governments will pursue further financial liberalization is limited by the fact that increasing financial internationalization increases the likelihood and severity of international financial crises by tightening international links that facilitate the transmission of financial shocks, increasing the scale and speed of international financial flows, expanding the interdependencies between increasingly large and complex financial institutions, and facilitating the growth of financial derivatives. For these reasons, and because there have been a number of serious international financial crises in recent years, governments are increasingly likely to act together to strengthen prudential regulation of financial institutions, as they have done just recently with the Basel 2 agreement.

So far it sounds like business has it all its own way, but in fact it is not all one-way traffic due to the emergence and growth of the anti-globalization movement in response to growing awareness of the downside of increasing economic internationalization (globalization), such as downward pressure on labor and environmental standards, threats to welfare states and economic damage to poor countries. For this reason the anti-globalization movement is likely to grow as economic internationalization develops just as trade unions expanded as industrialization progressed. Furthermore its political efficacy is increasing as developments in ICT improve the capacity of spatially-dispersed groups to coordinate at a distance. The consequence of this is increasing pressure on governments to counter the perceived ill effects of economic internationalization, for example by expanding the use of international agreements to regulate 
locational competition. Although there is little indication that this pressure will be sufficient to neutralize the pressures exerted on public policy by the economic and electoral implications of the growth of export industries, TNCs and international financial institutions, in part because, as we shall see, the policy leverage of trade unions is being eroded, it does seem likely to reduce their impact in areas such as tax, trade policy, and employment and environmental regulation.

\section{$\underline{4 .}$ Priority For Securing Energy Supplies Over Mitigating Climate Change.}

The increasing dependence of most EU countries on energy imports as energy use increases and domestic energy sources dwindle, combined with the centrality of energy to economic growth and societal functioning in general, increases the economic and electoral incentives for governments to implement more vigorous measures to ensure security of energy supply. This spur to action will be greatly strengthened if official forecasts that oil production will not peak until 2030 are wrong and in fact production peaks before then, as the continued increase in demand for oil, combined with falling supply, would lead to steadily rising oil prices that would raise price inflation and input costs while reducing non-oil demand and investment, leading to lower levels of economic activity and lower tax revenues, which in turn tend to lead among other things to bigger budget deficits, higher interest rates, higher unemployment, a deterioration in the balance of payments and lower exchange rates.

At the same time there is increasing evidence that climate change is real and that it is caused largely by the use of fossil fuels. This means increasing pressure on governments to take steps to reduce carbon emissions so as to avoid serious environmental and economic problems in the future, which implies increasing pressure on EU and other governments to reduce the use of fossil fuels.

Since economic growth is vital to the short-term electoral prospects of governments, however, measures to mitigate climate change are likely to be restricted to those that do not significantly constrain economic growth by making energy more expensive. At the same time governments will want to avoid measures that expand energy supply but exacerbate climate change. This means that the policies of choice are likely to be those that contribute both to energy security and to mitigating climate change at the same time, in particular policies designed to improve energy efficiency, encourage the development and use of alternative energy sources including nuclear power and renewables, shift passengers and freight to low carbon modes of transport, and encourage the substitution of communications for personal travel.

Ultimately, however, the priority given by EU and other governments to economic growth and re-election means that other policies will also be used to ensure energy security regardless of environmental considerations, such as diversifying foreign energy sources and supply routes and increasing diplomatic and military pressure on recalcitrant foreign governments.

What this means is that it is very unlikely that enough will be done to halt climate change. This in turn means that from time to time there will be natural disasters that can be attributed to climate change, each of which will stimulate adoption of more vigorous measures to mitigate climate change providing that these do not significantly obstruct economic growth. It also means that over time increasing pressure from those who are directly disadvantaged by climate change will lead governments to adopt more vigorous measures to adapt to it, for example by improving flood defenses. 
5. More Vigorous Measures to Increase the Size and Quality of the Labour Force.

One of the principal implications of population ageing is a reduction in the working-age population as a proportion of the total population. Other things being equal this implies a smaller labor force relative to the population as a whole and therefore lower economic growth and state revenue than would otherwise be the case. For this reason population ageing strengthens the incentives for governments to do what they can to counteract this effect by improving labor productivity and maximizing the size of the labor force. The concern to improve labor productivity, combined with the increasing economic significance of technology and growing unemployment among low-skilled workers, plus the fact that company provision of training is discouraged by the possibility that other firms may poach trained employees, strengthens the incentives for governments to expand education and training. At the same time the desire to increase the size of the labor force strengthens the incentives for governments to implement more vigorous measures to increase fertility, increase the proportion of women working, delay retirement and increase immigration.

\section{More Vigorous Measures to Facilitate Structural Adjustment.}

The increasing disruption of employment caused by expanding trade and the internationalization of production and finance strengthens the economic and electoral incentives for governments to help employees displaced by these processes through doing more to facilitate structural adjustment. One way of doing this is to provide more help with job search, retraining and financial assistance. Another option, and one that is particularly relevant in view of the fact that unemployment is higher among low-skilled workers, is to expand the supply of low-skilled service jobs by creating more low-skilled caring jobs in public sector social services and/or by facilitating the reduction of wages for workers in areas such as personal services in order to make it profitable for private employers in these areas to employ more people.

\section{More Business-Friendly Policies in General.}

In addition to the pressures to make public policy more business-friendly in specific areas there is also increasing pressure on governments to implement more business-friendly policies in general.

First, the growth in the proportion of viewers who watch commercial TV increases the proportion of the electorate that is exposed to media messages framed in such a way as to favour business and conservative (pro-business) parties and policies. Although experts in this area stress that media effects on the way that people think are likely to be significant only in the long term, and possibly not even then, to the extent that they do exist they imply a gradual increase in the vote for pro-business parties, other things being equal, and therefore a larger role in government for such parties. More generally the growth of pro-business views in the electorate would be expected to increase the electoral incentives for political parties and governments of all sorts to espouse more pro-business policies, resulting in increasing pressure on public policy to move in a pro-business direction. This media effect would be magnified by the fact that increasing levels of education imply increasing independence of mind on the part of voters and therefore that an increasing proportion of voters will cast their votes on the basis of media coverage of politics rather than habitual party identification. Although the growth of the Internet is likely to offset any pro-business effect to some extent by exposing a greater proportion of the electorate to antiestablishment views not normally carried on mainstream mass media, news on the Internet as 
elsewhere is always likely to be dominated by organizations that have abundant resources, which means the state and private companies.

The second reason to think that governments are becoming more likely to implement probusiness policies in general is the declining political leverage of trade unions, the traditional antagonists of employers on labor matters, as a consequence of membership losses due to job losses caused by automation, the decline of manufacturing (union density is lower in most areas of services), the increasing difficulty of organizing workers due to the increasing diversification of work, growing affluence that weakens workers' economic need of unions, rising levels of education that increase independence of mind and thereby undermine union membership and solidarity, increasingly diverse lifestyles that make it less likely that employees will identify strongly with unions, and declining leverage vis a vis employers due to the fact that the increasing internationalization of production increases the credibility of disinvestment threats by firms. Although there are also ways in which king trends might be expected to strengthen trade unions, their effects are unlikely to be substantial. Rising use of ICT improves union efficacy in areas such as recruitment, communications, coordination of campaigns and dissemination of the union case but this effect is counterbalanced by the fact that employers can use ICT to their advantage too. Increasing independence of mind among employees due to rising levels of education should make them more prepared to challenge the authority and decisions of employers, but as we have already noted this increasing independence of mind also undermines union membership and solidarity, and in any case it is not clear that employees are in fact becoming more prepared to challenge the boss. The other way in which king trends might be expected to strengthen trade unions is by making employees bolder due to a reduction in unemployment, and in the fear of unemployment, as a consequence of reductions in the size of the labor force due to population ageing. Although it is difficult to compare the magnitudes of these effects on trade unions, it seems likely that the net effect will be to weaken them, which implies decreasing pressure on governments to implement union-friendly policies and decreasing union resistance to the implementation by governments of more business-friendly policies.

The third reason to think that pressure to move public policy in a business-friendly direction in general is increasing is that working class influence on public policy is weakening due to a steady reduction in the proportion of traditional working class voters in the electorate as a consequence of automation and the decline of manufacturing employment. Other things being equal this implies a reduction in the vote for labor parties, a smaller role in government for such parties and diminishing electoral incentives for political parties and governments of all sorts to support the sorts of policies that benefit working class people where these conflict with the interests of employers.

\section{More Liberal Social Policies}

While king trends are pushing economic policy in a business-friendly direction in general, they are pushing social policy in a liberal direction in just a few respects, as follows.

\section{$\underline{\text { 8. Less Church-Friendly Policies. }}$}

Secularization in the form of falling religious affiliation and participation implies falling electoral support for parties of the right, in particular Christian parties, leading to a smaller role in government for these parties as well as dilution of the Christian content of the policies of these and other parties. It also erodes the capacity of churches to mobilize direct action. This in turn 
implies diminishing pressure on governments to maintain financial and other assistance for churches and church schools and therefore a gradual erosion of state support as time goes on.

Secularization also means that more and more people are acting, or wish to act, in ways that contravene traditional Christian morality but do not conflict with widely held secular norms. This strengthens the incentives for governments to remove laws that support or enforce traditional Christian morality in areas such as sexual behavior, marriage and divorce, abortion, family policy, the role of women, euthanasia and healthcare.

\section{More Women-Friendly Policies.}

As time goes on the political leverage of women is increasing. The fact that levels of education are rising faster for women than for men implies that the cognitive skills of women are rising relative to men. Increasing numbers of women are working, which means both that trade unions are likely to pursue women's issues more vigorously as the proportion of female union members and officials increases, and that increasing numbers of women are reaching influential positions in government and elsewhere. Governments wishing to maximize the size of the labor force by encouraging larger families are becoming convinced that women are more likely to have children when they are able to combine family and career than when they have to choose between them. And secularization is eroding the political leverage of churches and other policy actors that support the traditional Christian model of women as primarily wives and mothers.

In other words, the capacity of women to pursue their goals is growing, governments increasingly see advantage in making it easier for women to combine work and having a family, and support for the traditional Christian model of the role of women is weakening. This means that over time we should expect governments to implement more women-friendly policies, in the sense of more liberal feminist policies, in areas such as reproductive rights, childcare, family law, violence against women, employment regulation, equal rights in general, and the allocation of elected and appointed public positions.

\section{More Liberal Policies on Sexuality.}

The spread of more liberal attitudes towards sexuality, reinforced by the weakening of the hold of Christian sexual morality due to secularization, implies increasing electoral support for socially liberal parties, decreasing electoral support for Christian and conservative parties, electorally-motivated moderation of Christian and conservative party policies on sexual regulation, and weakening electoral incentives for governments of all complexions to keep laws enforcing Christian sexual morality. As a consequence we should expect the progressive liberalization of regulation relating to sexual activity, such as the extension to unmarried homosexual and heterosexual cohabiting couples of at least some of the legal protections and privileges accorded to married couples in areas such as taxation, inheritance, and division of property when relationships end.

We should also expect wider availability of contraception, better sex education and more liberal abortion laws as governments respond to the tendency of sexual liberalization in the form of earlier sexual activity, more sexual partners and more sex outside marriage to increase rates of unplanned pregnancies and sexually-transmitted diseases, including HIV/AIDS, in the context of increasing openness about sex. 
11. More Liberal Policies on the Cloning and Genetic Modification of Humans, and on Psychotropic Drugs.

One of the reasons that human cloning and inheritable genetic modification are illegal throughout the EU is that animal testing shows that these procedures are not safe. As technology develops, however, this is likely to change, thereby increasing the number of would-be parents who would like to take advantage of them. It also seems clear that sooner or later human clones and designer babies will be born whatever the legal situation. Both these developments will increase pressure on governments to legalize the cloning and inheritable genetic modification of humans.

A similar argument applies to psychotropic drugs: as scientists develop an increasing variety of relatively safe psychotropic drugs the number of people who would like to use them for work and/or recreation is likely to increase, leading to increasing pressure on governments to make these drugs legally available.

\section{Increased Public Spending}

12. Quasi-Automatic Increases in Spending on Health, Social Security and Defense.

Spending on health, social security and the armed forces has a tendency to increase by itself independent of discretionary decisions made by governments due to the increasing cost of healthcare technology and military technology, the increasing demand for pensions, healthcare and services for older people caused by population ageing and the consequent increase in the political leverage of older people, and the increasing demand for childcare, residential services, community services and home-based care caused by more people living alone or heading singleparent families and therefore lacking a second adult in the household to provide care in the case of illness or injury or, in the case of single parents, childcare.

\section{Conclusion}

The study on which this article is based was designed to obtain a synoptic view of the future direction of public policies in EU countries by using policy network theory and advocacy coalition theory to deduce the implications for public policy of all the major long-term technological, economic, environmental and social trends, or king trends, that I could identify and verify. Application of this methodology resulted in the identification of over a hundred policy implications, which were then condensed into 12 propositions about the future direction of public policy in EU Member States. Together these propositions suggest that we should expect more assertive security policies, more business-friendly economic policies, more liberal social policies and increased public spending (Table 3 ).

It is important to be quite clear what this list of 12 propositions represent. It is not a list of observed current policy trends extrapolated into the future but a list of the policy implications of king trends. And it is not a prediction of future trends in public policy but a list of those we would expect insofar as policy network theory and advocacy coalition theory correctly specify how king trends influence public policy, the king trends are correctly identified, and this influence is not obscured by events, personalities and other short-term and unpredictable factors. Another way of putting this is to say that these 12 points describe the directions in which public policy in Europe would move if only the 19 king trends were in operation, governments took the line of least resistance and nothing else changed much, with short-term fluctuations cancelling 
each other out and no major disruptive events. The actual future of public policy as it emerges can be thought of as a variation of this scenario.

Table 3. Net policy implications of king trends

\begin{tabular}{|c|c|}
\hline $\begin{array}{l}\text { General } \\
\text { categories }\end{array}$ & Implications \\
\hline $\begin{array}{l}\text { More assertive } \\
\text { security policies }\end{array}$ & $\begin{array}{l}\text { 1. More assertive foreign and security policies } \\
\text { 2. More intrusive and internationalized law enforcement }\end{array}$ \\
\hline $\begin{array}{l}\text { More business- } \\
\text { friendly } \\
\text { economic } \\
\text { policies }\end{array}$ & $\begin{array}{l}\text { 3. Increasingly favourable policies towards expanding firms and sectors } \\
\text { 4. Priority for securing energy supplies over mitigating climate change } \\
\text { 5. More vigorous measures to increase the size and quality of the labour } \\
\text { force } \\
\text { 6. More vigorous measures to facilitate structural adjustment } \\
\text { 7. More business-friendly policies in general }\end{array}$ \\
\hline $\begin{array}{l}\text { More liberal } \\
\text { social policies }\end{array}$ & $\begin{array}{l}\text { 8. Less church-friendly policies } \\
\text { 9. More women-friendly policies } \\
\text { 10. More liberal policies on sexuality } \\
\text { 11. More liberal policies on the cloning and inheritable genetic } \\
\text { modification of humans, and on psychotropic drugs }\end{array}$ \\
\hline $\begin{array}{l}\text { Increased public } \\
\text { spending }\end{array}$ & $\begin{array}{l}\text { 12. Quasi-automatic increases in spending on health, social security and } \\
\text { defence }\end{array}$ \\
\hline
\end{tabular}

The significance of this for those trying to build a better future by influencing public policy is that in specifying the directions in which public policy is likely to go, king trends theory also identifies the directions in which it is likely to be easy or difficult to push public policy. Awareness of the above scenario should therefore improve our ability to maximize implementation of our preferred policies, whatever these are, by enabling us to better target our efforts and resources on the pursuit of policy shifts that have a reasonable chance of coming to pass. Among other things this implies pursuing policy goals via policy instruments that are in line with the future policy trends specified by king trends theory, such as market-based instruments. It also implies dropping pursuit of policy shifts that are considered to be of relatively low priority where these run counter to the long-term policy trends identified above. King trends theory may appear to place more emphasis on structure than on agency, but to the extent that it yields a realistic picture of future policy trends - and it is the only synoptic picture of the long-term future of public policy that is based on realistic theories of how public policy is made - awareness of its findings should improve our capacity as purposive agents to influence the direction of public policy.

\section{Acknowledgements:}

I would like to thank the Leverhulme Trust for the Research Fellowship that enabled me to carry out this study. 


\section{REFERENCES}

Compston, Hugh. 2006. King trends and the future of public policy. Basingstoke: Palgrave.

Dowding, Keith. 1995. Model or metaphor? a critical review of the policy network approach. Political Studies 43: 136-58.

Parsons, D.W. 1995. Public policy. Cheltenham: Edward Elgar.

Rhodes, R.A.W. 1985. Power-dependence, policy communities and intergovernmental networks. Public Administration Bulletin 49: 4-31.

Sabatier, Paul A., and Hank Jenkins-Smith. 1999. The Advocacy Coalition Framework: an assessment. In Theories of the Policy Process. Ed. Sabatier, Paul A., 117-66. Boulder: Westview Press. 